\title{
PENGARUH AUDIT MANAJEMEN SUMBER DAYA MANUSIA TERHADAP KINERJA KARYAWAN
}

(Studi kasus pada PT. Gramedia Asri Media Bandar Lampung)

\section{Herry Goenawan Soedarsa \\ Chairul Anwar}

Shanti

(Universitas Bandar Lampung)

Email: herry.gs@ubl.ac.id

Email:chairul.anwar@ubl.ac.id

Email: Shan_ti93@yahoo.com

\begin{abstract}
PT. Gramedia Asri Media Bandar Lampung is a general bookstore that is engaged in the retail and distribution of books, school and office tools as well as multimedia products. The company as a business person should be able to deal with the changes and developments that exist both in the field of technology and social. Based on the description in the background, this research aims to determine the influence of Human Resource Management Audit against the Employee Performance at Gramedia Asri Media Bandar Lampung. The variables that examined in this research are Human Resource Management Audit (X) as Independent Variables and Performance $(Y)$ as the Dependent Variable. The population of this research is the parts that related to the audit of human resource management and employee performance. Sampling in this research is based on saturation sampling technique. In this research the number of the samples which are used is 43 respondents.

The data which is used in this research is primary data obtained from the questionnaires and interviews. To analyze the influence of Human Resource Management Audit $(X)$ Toward Performance $(Y)$, writer uses descriptive qualitative and quantitative methods, correlation coefficient, simple linear regression analysis, analysis of the coefficient of determination, and a $t$ test. Based on statistical analysis obtained the following results: $t$ test results are showed that the Human Resource Audit impact employee performance. This is indicated by tcount 5.743 while ttable of 1.68, based on the calculation that tcount $>$ ttable then $\mathrm{Ho}$ is rejected or in the other words $\mathrm{Ha}$ is accepted. Based on these findings it can be concluded that the hypothesis which states "Human Resource Management Audit influence on Employee Performance" is acceptable.
\end{abstract}

Keywords: Audit, human resources management, and employee performance 


\section{Latar Belakang}

Sumber daya manusia merupakan sumber daya yang paling penting dan sangat menentukan dalam mewujudkan tujuan perusahaan. Salah satu cara untuk memiliki sumber daya manusia yang handal adalah dengan di usahakannya suatu cara dalam meningkatkankan kinerja para karyawan secara efektif dan efisien, sehingga perusahaan tersebut dapat mencapai target yang telah direncanakan.

Ada beberapa fenomena yang menarik terjadi pada dunia kerja saat ini, antara lain, fenomena pertama yaitu dengan semakin bertambahnya perusahaan di Indonesia menyebabkan perusahaan harus mampu mempertahankan tenaga kerjanya yang profesional dan produktif agar tidak tertarik untuk pindah keperusahaan lain. Fenomena kedua yaitu perhatian audit sumber daya manusia belum banyak dilakukan padahal sebagai aset terpenting perusahaan, sumber daya manusia haruslah dapat dikembangkan semaksimal mungkin. Fenomena ketiga yaitu penempatan karyawan yang tidak sesuai dengan latar belakang pendidikannya. Hal ini akan menghambat usaha peningkatan produktivitas, karena kurangnya penguasaan karyawan akan bidang ilmu yang melatar belakangi pekerjaannya.

Pada PT. Gramedia Asri Media Bandar Lampung terdapat audit manajemen sumber daya manusia yang belum terlaksana dengan baik dimana perencanaan tenaga kerja yang ada belum dipersiapkan dengan matang karena masih terdapat penempatan karyawan yang tidak sesuai dengan bidang pekerjaannya. Sedangkan untuk kinerja karyawan, masih terdapat keterlambatan waktu dalam hal penyampaian laporan keuangan sehingga akan mempengaruhi pencapaian target perusahaan dimasa yang akan datang. Audit manajemen sumber daya manusia sangat penting untuk mengetahui efektifitas dan efisiensi keseluruhan fungsi sumber daya manusia dalam mengelola sumber daya manusia di perusahaan dan juga karena luasnya tanggung jawab fungsi ini yang meliputi seluruh perusahaan. Fungsi sumber daya manusia ini dapat ditingkatkan jika di tunjang oleh suatu pengendalian intern yang baik untuk menekan kemungkinan terjadinya kesalahan.

\section{Telaah Literatur dan Pengembangan Hipotesis}

\subsection{Teori yang Mendasari}

\section{Pengertian Audit dan Audit Manajemen}

Mulyadi et al (2009:9) menyatakan "Auditing merupakan suatu proses sistematik untuk memperoleh dan mengevaluasi bukti secara objektif mengenai pernyataan-pernyataan tentang kegiatan dan kejadian ekonomi, dengan tujuan untuk menetapkan tingkat kesesuaian antara 
pernyataan-pernyataan tersebut dengan kriteria yang telah ditetapkan, serta penyampaian hasil-hasilnya kepada pemakai yang berkepentingan".

Terjadi pengembangan kebutuhan dari audit keuangan ke audit non keuangan disebabkan adanya perasaan tidak puas terhadap hasil audit keuangan yang hanya berupa opini, yang disebut dengan audit manajemen. Untuk mengerti dengan jelas mengenai pengertian audit manajemen, berikut ini adalah pendapat beberapa ahli. Agoes (2004:10) menyatakan bahwa"Audit Manajemen adalah suatu pemeriksaan terhadap kegiatan operasi suatu perusahaan, termasuk kebijakan akuntansi dan kebijakan operasional yang telah ditentukan oleh manajemen, untuk mengetahui apakah kegiatan operasi tersebut sudah dilakukan secara efektif, efisien dan ekonomi." Sedangkan menurut Arens et al (2010) Audit operasionalmengevaluasiefisiensi dan efektivitas setiap bagian dari prosedur operasi organisasi dan metode. Pada penyelesaian audit operasional, manajemen biasanya mengharapkan rekomendasi untuk meningkatkan operasi.

\section{Pengertian Audit Sumber Daya Manusia}

Warther dan Davis (2003:560) mengatakan bahwa audit SDM adalah "suatu kegiatan pemeriksaan kualitas secara menyeluruh dari aktivitas yang dilakukan oleh sumber daya manusia pada suatu divisi atau perusahaan dan bagaimana kegiatan-kegiatan tersebut dapat mendukung strategi perusahaan". (The audit si an overall quality control check on HR activities in a division or company and on how those activity support the organisatiob strategy). Sedangkan Bayangkara (2011:60) mengemukakan bahwa audit sumber daya manusia merupakan penilaian dan analisis yang komprehensif terhadap program-program SDM. Dari beberapa pendapat tersebut maka dapat ditarik satu kesimpulan bahwa audit sumber daya manusia adalah seluruh upaya penelitian guna memeriksa kualitas secara menyeluruh dari aktivitas yang dilakukan oleh sumber daya manusia pada suatu divisi atau perusahaan untuk mendukung tercapainya tujuan perusahaan.

\section{Laporan Audit Manajemen Sumber Daya Manusia}

Menurut Hamilton (2008), laporan audit manajemen sumber daya manusia meliputi empat bagian, yaitu:

1. Tujuan dan ruang lingkup audit

Bagian ini menjelaskan tujuan yang hendak dicapai, bagian yang akan diaudit, dan metode apa yang digunakan dalam audit manajemen SDM. 
2. Ringkasan dan kesimpulan

Ringkasan merupakan gambaran umum dari hasil audit manajemen SDM yang mencakup kesimpulan akhir dan opini dari tim auditor.

3. Temuan-temuan audit

Semua penyimpangan yang terjadi merupakan temuan audit yang mendukung isi dari laporan audit.

4. Rekomendasi atau saran

Bagian ini berisi alternatif tindakan yang dapat diambil oleh manajemen untuk memperbaiki kinerja, mengembangkan sumber daya manusia, serta untuk memenuhi kebutuhan karyawan yang berkualitas pada setiap departemen yang ada dalam perusahaan.

\section{Pengertian Manajemen Sumber Daya Manusia}

Manajemen SDM (Sumber Daya Manusia) sebagai cabang dari Manajemen, adalah merupakan seni dan ilmu. Hanya perbedaannya, jika manajemen menitikberatkan perhatiannya kepada soal-soal manusia dalam hubungan kerja dengan tidak melupakan faktor-faktor produksi lainnya, maka manajemen SDM ini khusus menitikberatkan perhatiannya kepada faktor produksi tenaga kerja.

Arti dari SDM itu sendiri menurut Handoko (2004:5) adalah sebagai suatu fungsi untuk menjalin kerjasama dalam pengembangan dan administrasi. Berbagai kebijakan yang mempengaruhi orang-orang yang membentuk organisasi dan untuk membantu para manajer mengelola SDM. Menurut Rivai (2009:1)"Manajemen Sumber Daya Manusia (MSDM) merupakan salah satu bidang dari manajemen umum yang meliputi segi-segi perencanaan, pengorganisasian, pelaksanaan dan pengendalian".

\section{Pengertian Kinerja dan Perencanaan Kinerja}

Menurut Schermerhorn (1999:309), kinerja adalah: Kuantitas dan kualitas kerja yang diselesaikan oleh perseorangan atau kelompok. Sedangkan menurut Byars dan Rue (2004:250), kinerja adalah: Tingkat penyelesaian tugas-tugas yang merupakan hasil pekerjaan perorangan. Bacal (2002:65), mendefinisikan perencanaan kinerja: Suatu proses dimana karyawan dan manajer bekerja sama untuk menentukan apa yang seharusnya dilakukan oleh karyawan pada tahun berikutnya dan apa yang dinamakan kinerja yang sukses. Menurut Moorhead dan Griffin (1995:189), perencanaan kinerja: Sebuah pemahaman antara seorang 
karyawan dengan manajer tentang apa dan bagaimana pekerjaan diselesaikan, sehingga keduanya tahu apa yang diharapkan dan bagaimana keberhasilan ditetapkan.

\section{Indikator-indikator Kinerja}

Umar (2002:102), mengidentifikasi indikator-indikator kinerja sebagai berikut:

a. Kualitas pekerjaan

Sejauh mana karyawan dapat menyelesaikan pekerjaan dengan kualitas yang baik.

b. Inisiatif

Karyawan mampu mengembangkan pikiran dan melaksanakan suatu pekerjaan tanpa diberi perintah oleh atasan.

c. Etika kerja

Mengacu pada kemampuan terhadap pemahaman tugas dalam hubungan kerja dengan lingkungan kerja.

d. Kerja sama

Kemampuan dalam menjalin hubungan yang baik dengan rekan kerja dalam melaksanakan dan menyelesaikan pekerjaan secara bersama.

e. Pengetahuan tentang pekerjaan

Pemahaman dan penguasaan pengetahuan dan prosedur yang diperlukan untuk menunjang keberhasilan suatu pekerjaan.

f. Tanggung jawab

Mengacu pada penyelesaian tugas yang didelegasikan oleh atasan.

g. Pemanfaatan waktu

Sesuai tidaknya dengan waktu yang direncanakan perusahaan dalam menyelesaikan tugas yang diberikan pada karyawan.

\section{Hubungan Audit Manajemen dengan Kinerja Karyawan}

Hubungan antara audit sumber daya manusia dengan kinerja dapat dilihat dari dalil-dalil yang dikemukakan oleh Susilo (2002:28) "Setelah perencanaan audit sumber daya manusia dilanjutkan dengan pelaksanaan audit sumber daya manusia selanjutnya adalah kegiatan pengukuran kinerja, yaitu suatu proses-proses mengkuantifikasikan secara akurat dan valid tingkat efisiensi dan efektivitas suatu kegiatan yang telah terealisasi dan membandingkannya dengan tingkat prestasi yang direncanakan”. 
Siagian (2001:31) menyatakan "Pelaksanaan audit sumber daya manusia bermuara pada ketiga aspek kinerja manajerial yang dapat dan harus dijadikan sasaran audit yaitu, pertama, kemampuan sumber daya manusia memainkan perannya; kedua, ketangguhan sumber daya manusia menyelenggarakan berbagai aktivitasnya; ketiga, keterampilan manajer perusahaan yang dihadapkan kepada berbagai tantangan, baik yang sifatnya eksternal maupun internal". Dari beberapa pendapat diatas, dapat disimpulkan bahwa dengan melaksanakan audit sumber daya manusia dalam suatu perusahaan, maka akan memberikan feed back kepada perusahaan untuk kemudian digunakan dalam mengukur tingkat kinerja masing-masing SDM dan selanjutnya dicari solusi untuk meningkatkan kinerja SDM tersebut.

\subsection{Penelitian Terdahulu}

Lintoman Sagala (2009) dengan judul penelitian Pengaruh Pelaksanaan Audit Manajemen Sumber Daya Manusia Terhadap Tingkat Produktivitas Sumber Daya Manusia Pada PT. Ultrajaya Milk Industry \& Trading Company Tbk. menyatakan bahwa Audit Manajemen Sumber Daya Manusia berpengaruh terhadap tingkat Produktivitas Sumber Daya Manusia dengan nilai koefisien korelasi 0,82 yang termasuk ke dalam kategori sangat kuat karena berada diantara nilai koefisien korelasi 0,80-1,00 yang menyatakan bahwa keberadaan audit manajemen sumber daya manusia berpengaruh dalam meningkatkan produktivitas.

Diajeng Ratih (2011) dengan judul penelitian Persepsi Audit Manajemen Sumber Daya Manusia Terhadap Peningkatan Kinerja Karyawan PT. Jasa Marga (Persero) Tbk. menyatakan bahwa audit manajemen sumber daya yang terdiri dari perencanaan tenaga kerja, penyelenggaraan fungsi rekrutmen, penyelenggaraan fungsi orientasi dan penempatan, penyelenggaraan fungsi seleksi serta fungsi pelatihan dan pengembangan memiliki pengaruh yang sangat signifikan terhadap kinerja karyawan, semakin tinggi perbaikan peningkatan audit manajemen sumber daya manusia maka semakin tinggi juga peningkatan kinerja karyawan. 
Kerangka Pemikiran Teoritis

\begin{tabular}{|c|c|}
\hline $\begin{array}{c}\text { Audit Manajemen } \\
\text { Sumber Daya Manusia(X) }\end{array}$ & $\begin{array}{l}\text { Kinerja } \\
(\mathbf{Y})\end{array}$ \\
\hline $\begin{array}{l}\text { - Tujuan dan Ruang Lingkup } \\
\text { Audit } \\
\text { - Ringkasan dan Kesimpulan } \\
\text { - Temuan-temuan Audit } \\
\text { - Rekomendasi atau Saran } \\
\text { (Hamilton (2008)) }\end{array}$ & $\begin{array}{l}\text { - Kualitas Pekerjaan } \\
\text { - Inisiatif } \\
\text { - Etika Kerja } \\
\text { - Kerja Sama } \\
\text { - Pengetahuan Tentang Pekerjaan } \\
\text { - Tanggung Jawab } \\
\text { - Pemanfaatan Waktu } \\
\text { (Umar (2002:102)) }\end{array}$ \\
\hline
\end{tabular}

\section{Gambar 1 Paradigma Penelitian}

\section{Metodologi Penelitian}

\subsection{Pemilihan Sampel}

Sampel dalam penelitian ini adalah seluruh karyawan yang menjadi objek pemeriksaan sumber daya manusia, dan orang-orang yang berhubungan dengan produktivitas kerja yaitu bagian sumber daya manusia. Jumlah sampel adalah seluruh responden dari jumlah populasi yaitu 44 responden. Teknik pengambilan sampel adalah Teknik Nonprobability sampling dengan menggunakan sampling jenuh. Sampling jenuh adalah teknik penentuan sampel bila anggota populasi digunakan sebagai sampel. (Sugiyono, 2011:64).

\subsection{Data}

Penelitian ini menggunakan jenis data primer yaitu merupakan data yang didapat dari sumber pertama, dari individu seperti hasil wawancara dan hasil penelitian kuesioner yang bersumber dari PT. Gramedia Asri Media Bandar Lampung.

\subsection{Model Penelitian dan Pengujian Statistik}

\section{Model Penelitian}

Jenis dan desain penelitian yang digunakan adalah eksploratif dan kausalitas. Penelitian eksploratif adalah penelitian yang digunakan untuk mengumpulkan data-data awal tentang sesuatu (Irawan, 2007:101). Desain kausalitas adalah penelitian yang bertujuan menganalisis hubungan sebab-akibat antara variabel independen dan dependen (Sugiyono, 2011:30). 


\section{Pengujian Statistik}

\section{Teknik Analisa Data}

\section{Analisis Kualitatif}

Analisis kualitatif yaitu data yang tidak berbentuk angka, namun menunjukkan kelaskelas atau jenjang-jenjang dari variabel itu sendiri. Pada penelitian ini metode yang digunakan adalah metode deskriptif, tujuannya yaitu suatu metode dalam meneliti sejumlah manusia, objek, kondisi, system, pemikiran atau suatu peristiwa pada masa sekarang tujuannya adalah untuk membuat deskriptif secara sistematis dan akurat mengenai fakta, serta pengaruh antara variabel. Untuk mengetahui gambaran mengenai bagaimana pengaruh Audit Manajemen Sumber Daya Manusia terhadap kinerja karyawan PT. Gramedia Asri Media Bandar Lampung dapat dilakukan dengan menyebarkan kuesioner kepada karyawan PT. Gramedia Asri Media Bandar Lampung dengan menggunakan metode skala likert (Likert Scale). Untuk mengukur pengaruh audit manajemen sumber daya manusia terhadap kinerja karyawan, diukur dengan perhitungan SPSS versi 17.0.

Tabel 1

Bobot Nilai Jawaban Questionnaire berdasarkan Skala Likert

\begin{tabular}{|l|l|}
\hline Jawaban & Nilai \\
\hline Sangat Setuju (SS) & 5 \\
\hline Setuju (S) & 4 \\
\hline Ragu-Ragu (RG) & 3 \\
\hline Tidak Setuju (TS) & 2 \\
\hline Sangat Tidak Setuju (STS) & 1 \\
\hline
\end{tabular}

\section{Analisis Kuantitatif}

Analisis kuantitatif yaitu data dalam bentuk angka-angka, data disini menunjukkan adanya jumlah dari variabel itu sendiri.

\section{a. Uji Validitas}

Uji validitas digunakan untuk mengukur sah atau valid tidaknya suatu kuesioner. Suatu kuesioner dikatakan valid jika pertanyaan pada kuesioner mampu untuk mengungkapkan sesuatu yang akan diukur oleh kuesioner tersebut (Ghozali, 2009:49). Pengukuran validitas dalam penelitian ini dilakukan dengan menggunakan Corrected item-Total correlation. 


\section{b. Uji Reliabilitas}

Uji reliabilitas adalah pengujian untuk mengukur suatu kuesioner yang merupakan indikator dari variabel. Disini pengukuran hanya dilakukan sekali dan kemudian hasilnya dibandingkan dengan pertanyaan lain. Suatu variabel dikatakan reliabel jika nilai Cronbach's Alpha $>$ 0,60, jika sebaliknya data tersebut dikatakan tidak reliabel (Ghozali, 2009:45).

\section{c. Analisis regresi linear sederhana (Simple Linear Regression)}

Analisis regresi linier sederhana adalah suatu metode untuk menguji sejauh mana hubungan sebab akibat antara variabel bebas (X) terhadap variabel terikat (Y). Data yang telah dikumpulkan dianalisis dengan menggunakan alat analisis statistik yakni analisis regresi linier sederhana dinyatakan dengan persamaan:

$$
\mathbf{Y}=\mathbf{a}+\mathbf{b X}
$$

Keterangan:

$\mathrm{Y} \quad=$ Kinerja

$\mathrm{a} \quad=$ Konstanta

$\mathrm{b} \quad=$ Koefisien regresi

$\mathrm{X}=$ Audit Manajemen Sumber Daya Manusia

\section{d. Koefisien Korelasi}

Koefisiean korelasi adalah suatu metode untuk mengetahui keeratan hubungan antara variable $\mathrm{X}$ terhadap variabel $\mathrm{Y}$.

Tabel 2

Interprestasi Koefisien Nilai r

\begin{tabular}{|l|l|}
\hline Interval Koefisien & Tingkat Hubungan \\
\hline $0,00-0,199$ & Sangat Lemah \\
\hline $0,21-0,399$ & Lemah \\
\hline $0,40-0,599$ & $\begin{array}{l}\text { Sedang (Tidak lemah, Tidak } \\
\text { kuat) }\end{array}$ \\
\hline $0,60-0,799$ & Kuat \\
\hline $0,80-1,00$ & Sangat Kuat \\
\hline
\end{tabular}

(Sumber: Riduwan. 2005:228) 


\section{Uji Hipotesis}

\section{Uji t (Test of Significant)}

Uji statistik $\mathrm{t}$ pada dasarnya menunjukkan seberapa jauh pengaruh suatu variabel independen terhadap variabel dependen dengan menganggap variabel lainnya konstan (Ghozali, 2009). Kriteria pengambilan keputusan adalah sebagai berikut:

- $\quad$ Apabila $t$ hitung $>\mathrm{t}$ tabel dan tingkat signifikan $(\alpha)<0,05$ maka Ho ditolak. Ini berarti secara parsial variabel independen berpengaruh signifikan terhadap variabel dependen.

- $\quad$ Apabila t hitung $<\mathrm{t}$ tabel dan tingkat signifikan $(\alpha)>0,05$ maka Ho diterima, yang berarti secara parsial variabel independen tidak berpengaruh signifikan terhadap variabel dependen.

\section{Koefisien Determinasi $\left(\mathbf{R}^{2}\right)$}

Koefisien determinasi digunakan untuk menguji besarnya persentase variabel dependen yang dapat dijelaskan oleh variabel independen. Nilai koefisien determinasi adalah antara nol dan satu. Nilai yang kecil berarti kemampuan variabel independen sangat terbatas. Nilai yang mendekati satu berarti kemampuan variabel independen memberikan hampir semua informasi yang dibutuhkan untuk memprediksi variasi variabel dependen (Ghozali, 2009).

\subsection{Definisi Operasional Variabel Penelitian}

\section{Variabel Independen}

\section{Audit Manajemen Sumber Daya Manusia (X)}

Audit Manajemen Sumber Daya Manusia adalah suatu pemeriksaan terhadap kegiatan operasi suatu perusahaan, termasuk kebijakan akuntansi dan kebijakan operasional yang telah ditentukan oleh manajemen, untuk mengetahui apakah kegiatan operasi tersebut sudah dilakukan secara efektif, efisien dan ekonomis.

\section{Variabel Dependen}

\section{Kinerja (Y)}

Manajemen kinerja karyawan adalah suatu pola tindakan yang dilaksanakan untuk mencapai tujuan perusahaan atau gambaran mengenai tingkat pencapaian pelaksanaan suatu kegiatan/program/kebijaksanaan dalam mewujudkan sasaran, tujuan, misi, dan visi organisasi yang tertuang dalam perumusan skema strategis (strategis planning) suatu organisasi. 


\section{Hasil dan pembahasan}

\subsection{Data Penelitian}

\section{Gambaran Umum Responden}

Kuesioner yang disebarkan penulis dalam penelitian ini berjumlah 44 kuesioner dengan subjek penelitian adalah seluruh karyawan yang terdapat di PT. Gramedia Asri Media Bandar Lampung. Dari 44 kuesioner yang disebarkan ke 44 karyawan sebagai responden, hanya 43 yang kembali dan dinyatakan lengkap untuk diproses lebih lanjut.

\section{Profil Responden}

Untuk mendapatkan gambaran yang jelas mengenai responden, dibawah ini akan dijabarkan profil dari 43 responden berdasarkan 4 kriteria. Kriteria-kriteria tersebut antara lain adalah jenis kelamin, usia, tingkat pendidikan, dan masa bekerja. Berdasarkan data yang diperoleh dari penyebaran kuesioner terhadap 43 responden, maka diperoleh:

\section{Gambar 2}

\section{Karakteristik Responden Berdasarkan Jenis Kelamin}

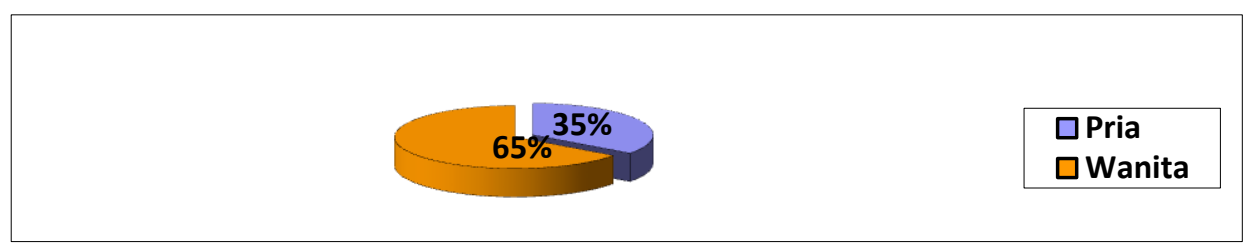

Sumber: data diolah, 2013

Berdasarkan gambar 2, dapat dilihat bahwa responden didominasi oleh wanita. Hal ini dapat dilihat dari jumlah responden, 28 orang (65\%) berjenis kelamin wanita dan 15 orang $(35 \%)$ berjenis kelamin pria.

\section{Gambar 3}

\section{Karakteristik Responden Berdasarkan Usia}

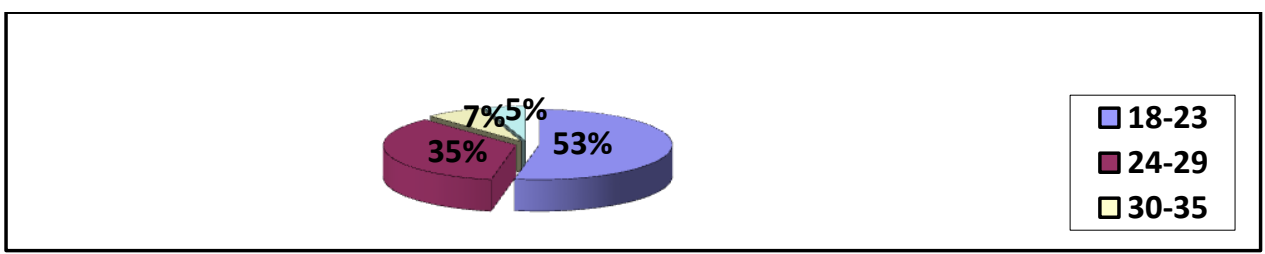

Sumber: data diolah, 2013 
Dari 43 responden, yang berusia diantara 18-23 tahun berjumlah 23 orang (53\%), responden berusia 24-29 tahun berjumlah 15 orang (35\%), dan responden berusia 30-35 tahun berjumlah 3 orang (7\%), sedangkan responden yang berusia diatas 36 tahun berjumlah 2 orang $(5 \%)$. Artinya responden didominasi oleh orang-orang yang masih produktif.

\section{Gambar 4}

Karakteristik Responden Berdasarkan Tingkat Pendidikan

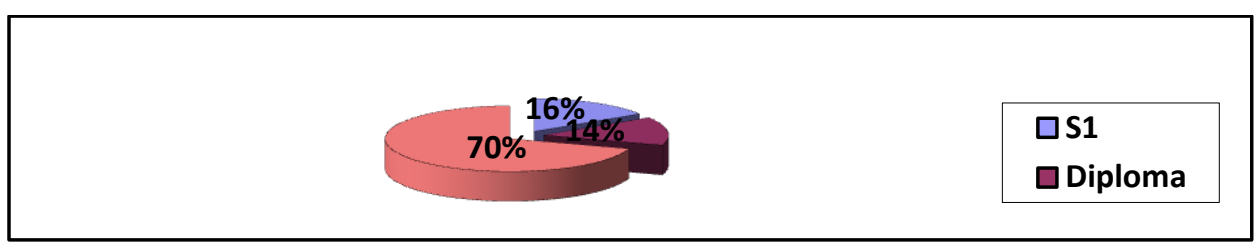

Sumber: data diolah, 2013

Berdasarkan gambar 4 dapat dilihat bahwa responden yang yang berpendidikan S1 berjumlah 7 responden (16\%), yang memiliki tingkat pendidikan Diploma/Sederajat berjumlah 6 responden (14\%), dan ditingkat SMA/Sederajat berjumlah 30 responden (70\%).

Gambar 5

Karakteristik Responden Berdasarkan Masa Kerja

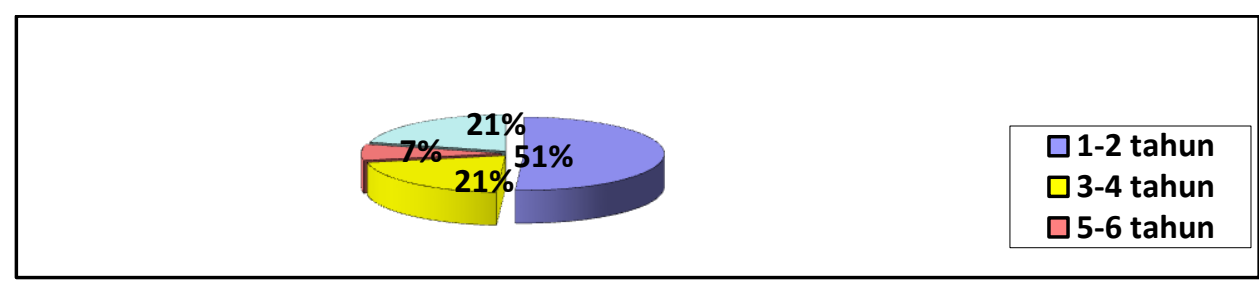

Sumber: data diolah, 2013

Berdasarkan gambar 5dapat dilihat bahwa responden yang memiliki masa kerja diantara 1-2 tahun berjumlah 22 responden (51\%), yang memiliki masa kerja diantara 3-4 tahun berjumlah 9 responden (21\%), dan yang memiliki masa kerja diantara 5-6 tahun berjumlah 3 responden $(7 \%)$, sedangkan yang $>6$ tahun berjumlah 9 responden $(21 \%)$.

\section{Analisis Deskriptif}

\section{Tanggapan Responden atas Audit Manajemen SDM (X)}

Untuk mengukur audit manajemen sumber daya manusia ini digunakan instrumen sebanyak 10 pernyataan yang mewakili 4 indikator yaitu: tujuan dan ruang lingkup audit, ringkasan dan kesimpulan, temuan-temuan audit, dan ringkasan atau saran, untuk mengetahui 
kriteria jawaban diatas maka digunakan rumus interval kelas dengan rentang skor nilai terendah 43 dan tertinggi 215 dengan alternatif jawaban 1-5, dan hasil perhitungannya dengan rumus menurut Deutschabteilung UPI (2008):

$$
\text { Interval }=\frac{\mathrm{NT}-\mathrm{NR}}{\mathrm{K}}, \quad \text { Interval }=\frac{215-43}{5}=34
$$

Keterangan:

NT : Nilai total skor tertinggi

NR : Nilai total skor terendah

K : Kategori

Berdasarkan perhitungan diatas diperoleh interval kelas sebesar 34, maka dapat ditentukan kriteria jawaban untuk masing-masing variabel:

Tabel 3

Kriteria Jawaban Responden

\begin{tabular}{|l|l|}
\hline Interval Kelas & Kriteria Jawaban \\
\hline $181-215$ & Sangat Baik \\
\hline $146-180$ & Baik \\
\hline $111-145$ & Sedang \\
\hline $76-110$ & Cukup Baik \\
\hline $43-75$ & Kurang Baik \\
\hline
\end{tabular}

Sumber: data diolah, 2013

Berdasarkan hasil jawaban responden atas kuesioner mengenai audit manajemen sumber daya manusia pada PT. Gramedia Asri Media Bandar Lampung, diperoleh rekapitulasi total skor dan kriteria jawaban: 
Tabel 4

Rekapitulasi Total Skor Per Item Pernyataan dan Kriteria Jawaban atas Audit Manajemen Sumber Daya Manusia (X)

\begin{tabular}{|l|l|l|l|l|}
\hline No. & Pernyataan & $\begin{array}{l}\text { Skor } \\
\text { Harapan }\end{array}$ & Skor Rill & Kriteria \\
\hline 1 & P1 & 215 & 177 & Baik \\
\hline 2 & P2 & 215 & 168 & Baik \\
\hline 3 & P3 & 215 & 167 & Baik \\
\hline 4 & P4 & 215 & 177 & Baik \\
\hline 5 & P5 & 215 & 163 & Baik \\
\hline 6 & P6 & 215 & 174 & Baik \\
\hline 7 & P7 & 215 & 174 & Baik \\
\hline 8 & P8 & 215 & 178 & Baik \\
\hline 9 & P9 & 215 & 168 & Baik \\
\hline 10 & P10 & 215 & 177 & Baik \\
\hline & Rata-rata & $\mathbf{2 1 5}$ & $\mathbf{1 7 2}$ & Baik \\
\hline
\end{tabular}

Sumber: data diolah, 2013

Berdasarkan tabel 4 diatas dapat dijelaskan bahwa nilai rata-rata jawaban responden atas seluruh item pernyataan tentang audit manajemen sumber daya manusia pada PT. Gramedia Asri Media Bandar Lampung yang diukur sebesar 172 dengan kriteria "Baik". Ini menggambarkan bahwa rata-rata audit manajemen pada PT. Gramedia Asri Media Bandar Lampung adalah baik.

\section{Tanggapan Responden atas Kinerja (Y)}

Untuk mengukur kinerja ini dipergunakan instrumen sebanyak 10 pernyataan yang mewakili 7 indikator yaitu: kualitas pekerjaan, inisiatif, etika kerja, kerja sama, pengetahuan tentang pekerjaan, tanggung jawab, dan pemanfaatan waktu, dimana setiap butir pernyataan memiliki rentang nilai 1 sampai dengan 5. Berdasarkan hasil jawaban responden atas kuesioner tentang peningkatan kinerja pada PT. Gramedia Asri Media diperoleh: 
Tabel 5

Rekapitulasi Total Skor Per Item Pernyataan dan Kriteria Jawaban atas Peningkatan Kinerja (Y)

\begin{tabular}{|c|c|c|c|c|}
\hline No. & Pernyataan & $\begin{array}{c}\text { Skor } \\
\text { Harapan }\end{array}$ & Skor Rill & Kriteria \\
\hline 1 & P1 & 215 & 176 & Baik \\
\hline 2 & P2 & 215 & 170 & Baik \\
\hline 3 & P3 & 215 & 175 & Baik \\
\hline 4 & P4 & 215 & 181 & Sangat Baik \\
\hline 5 & P5 & 215 & 191 & Sangat Baik \\
\hline 6 & P6 & 215 & 179 & Baik \\
\hline 7 & P7 & 215 & 177 & Sangat Baik \\
\hline 8 & P9 & 215 & 175 & Baik \\
\hline 9 & P10 & 215 & 177 & Baik \\
\hline 10 & Rata-rata & $\mathbf{2 1 5}$ & $\mathbf{1 7 9}$ & Baik \\
\hline & & & 187 \\
\hline
\end{tabular}

Sumber: data diolah, 2013

Berdasarkan tabel 5 dapat dijelaskan bahwa jawaban responden atas item pernyataan dengan indikator etika kerja, kerja sama, dan pengetahuan tentang pekerjaan adalah sangat baik. Sedangkan nilai rata-rata untuk seluruh item pernyataan tentang kinerja karyawan pada PT. Gramedia Asri Media Bandar Lampung yang diukur sebesar 179 dengan kriteria "Baik". Ini menggambarkan bahwa rata-rata kinerja karyawan pada PT. Gramedia Asri Media Bandar Lampung adalah baik.

\subsection{Pengujian Kualitas Data}

\section{Uji Validitas Variabel X dan Y}

Pengujian validitas item pernyataan untuk variabel X dan Y sebanyak 10 item. Untuk mencari validitas item pernyataan digunakan Corrected item-Total correlation. Berdasarkan hasil pengolahan data: 
Tabel 6

Hasil Uji Validitas Variabel Audit Manajemen Sumber Daya Manusia (X)

\begin{tabular}{|l|l|l|l|l|}
\hline Pernyataan & r hitung & r tabel & Kondisi & Keterangan \\
\hline P1 & 0,325 & 0,25 & r hitung $>r$ tabel & Valid \\
\hline P2 & 0,351 & 0,25 & r hitung $>$ r tabel & Valid \\
\hline P3 & 0,312 & 0,25 & r hitung $>r$ tabel & Valid \\
\hline P4 & 0,307 & 0,25 & r hitung $>r$ tabel & Valid \\
\hline P5 & 0,623 & 0,25 & r hitung $>r$ tabel & Valid \\
\hline P6 & 0,632 & 0,25 & r hitung $>r$ tabel & Valid \\
\hline P7 & 0,391 & 0,25 & r hitung $>r$ tabel & Valid \\
\hline P8 & 0,582 & 0,25 & $r$ hitung $>r$ tabel & Valid \\
\hline P9 & 0,332 & 0,25 & r hitung $>r$ tabel & Valid \\
\hline P10 & 0,619 & 0,25 & $r$ hitung $>r$ tabel & Valid \\
\hline
\end{tabular}

Sumber: data diolah 2013

Tabel 7

Hasil Uji Validitas Variabel Peningkatan Kinerja (Y)

\begin{tabular}{|l|l|l|l|l|}
\hline Pernyataan & r hitung & r tabel & Kondisi & Keterangan \\
\hline P1 & 0,678 & 0,25 & r hitung $>$ r tabel & Valid \\
\hline P2 & 0,758 & 0,25 & r hitung $>$ r tabel & Valid \\
\hline P3 & 0,432 & 0,25 & r hitung $>$ r tabel & Valid \\
\hline P4 & 0,367 & 0,25 & r hitung $>$ r tabel & Valid \\
\hline P5 & 0,277 & 0,25 & r hitung $>$ r tabel & Valid \\
\hline P6 & 0,402 & 0,25 & r hitung $>$ r tabel & Valid \\
\hline P7 & 0,709 & 0,25 & r hitung $>$ r tabel & Valid \\
\hline P8 & 0,833 & 0,25 & $r$ hitung $>r$ tabel & Valid \\
\hline P9 & 0,626 & 0,25 & $r$ hitung $>r$ tabel & Valid \\
\hline P10 & 0,385 & 0,25 & $r$ hitung $>r$ tabel & Valid \\
\hline
\end{tabular}

Sumber: data diolah 2013 
Tabel 6 dan 7 menggambarkan bahwa seluruh item pernyataan dalam kuesioner adalah valid. Dikatakan valid karena nilai koefisien korelasi Pearson Correlation $\left(\mathrm{r}_{\text {hitung }}\right.$ ) lebih besar dari $r_{\text {tabel }}$ yaitu 0,25. Maka seluruh item tersebut dapat dilanjutkan untuk pengujian reliabilitas.

\section{Uji Reliabilitas}

Tabel 8

Hasil Uji Reliabilitas Variabel X dan Y

\begin{tabular}{|l|l|l|l|l|l|}
\hline No & $\begin{array}{l}\text { Variabel } \\
\text { Penelitian }\end{array}$ & $\begin{array}{l}\text { N of } \\
\text { Item }\end{array}$ & $\begin{array}{l}\text { Cronbach's } \\
\text { Alpha }\end{array}$ & $\begin{array}{l}\text { Std } \\
\text { Reliabilitas }\end{array}$ & Keterangan \\
\hline 1. & $\begin{array}{l}\text { Audit Manajemen } \\
\text { SDM }\end{array}$ & 10 & 0.732 & 0.60 & Reliabel \\
\hline 2. & Kinerja & 10 & 0.848 & 0.60 & Reliabel \\
\hline
\end{tabular}

Sumber: data diolah 2013

Berdasarkan hasil uji reliabilitas diatas, tampak nilai koefisiensi Cronbach's Alpha untuk semua variabel penelitian menunjukkan nilai koefisien Cronbach's Alpha lebih besar dari nilai batas minimum yaitu 0.60, Nunnaly (2006) sehingga semua variabel dapat dikatakan reliabel.

\section{Analisis Regresi Linier Sederhana}

\section{Tabel 9}

Hasil Uji Analisis Regresi Linier Sederhana

Coefficients $^{\mathrm{a}}$

\begin{tabular}{|l|l|l|l|}
\hline \multirow{2}{*}{ Model } & \multicolumn{2}{|l|}{ Unstandardized Coefficients } & Standardized Coefficients \\
\cline { 2 - 4 } & $\mathrm{B}$ & Std. Error & Beta \\
\hline 1 (Constant) & 10.877 & 5.381 & \\
$\mathrm{X}$ & .766 & .133 & .668 \\
\hline
\end{tabular}

a. Dependent Variable: Y

Berdasarkan pada tabel 9 diperoleh persamaan regresi linier sederhana:

$$
Y=10.877+0.766 X
$$


Konstanta sebesar 10.877 adalah memberi pengertian bahwa jika pengaruh audit manajemen sumber daya manusia terhadap kinerja karyawan PT. Gramedia Asri Media Bandar Lampung adalah konstanta atau sama dengan nol (0), maka besarnya kemampuan kinerja pada PT. Gramedia Asri Media Bandar Lampung sebesar 10.877 satuan.Hal ini menginformasikan bahwa audit manajemen sumber daya manusia yang terdiri dari tujuan dan ruang lingkup audit, ringkasan dan kesimpulan, temuan-temuan audit, dan rekomendasi atau saran memiliki pengaruh yang sangat signifikan terhadap kinerja karyawan, semakin tinggi perbaikan peningkatan audit manajemen sumber daya manusia maka semakin tinggi juga peningkatan kinerja karyawan.

Sedangkan X yang merupakan koefisien regresi dari variabel audit manajemen sumber daya manusia sebesar 0.766 mempunyai arti bahwa bila terjadi perbaikan audit manajemen terhadap kinerja karyawan pada PT. Gramedia Asri Media Bandar Lampung sebesar 1 satuan, maka akan terjadi peningkatan terhadap kinerja karyawan sebesar 0.766 satuan dengan asumsi variabel lainnya konstan atau tetap. Dari hasil analisis regresi ditemukan adanya hubungan antara variabel independen dan dependen, bahwa jika audit manajemen sumber daya manusia meningkat maka kinerja karyawan pada PT. Gramedia Asri Media Bandar Lampung akan mengalami peningkatan pula.

\section{Koefisien Korelasi}

\section{Tabel 10}

\section{Hasil Uji Koefisien Korelasi}

\begin{tabular}{|l|l|l|l|l|}
\multicolumn{3}{|c|}{ Model Summary $^{\mathbf{b}}$} \\
\hline Model & R & R Square & Adjusted R Square & Std. Error of the Estimate \\
\hline 1 & $.668^{\mathrm{a}}$ & .446 & .432 & 4.005 \\
\hline
\end{tabular}

a. Predictors: (Constant), X

b. Dependent Variable: Y

Berdasarkan tabel 10 diperoleh besarnya koefisien korelasi adalah 0,668. Artinya, hubungan antara variabel $\mathrm{X}$ dan $\mathrm{Y}$ adalah 0,668. Hal ini termasuk kedalam kategori kuat berdasarkan interprestasi nilai r yaitu berada diantara 0,60-0,799 yang menunjukkan bahwa pelaksanaan audit manajemen sumber daya manusia pada PT. Gramedia Asri Media Bandar Lampung berpengaruh positif terhadap kinerja karyawan dengan tingkat keeratan kuat. 


\subsection{Pengujian Hipotesis}

Uji t

Tabel 11

Hasil Uji t Statistik

Coefficients $^{\mathbf{a}}$

\begin{tabular}{|c|c|c|c|c|c|c|}
\hline \multirow{2}{*}{\multicolumn{2}{|c|}{ Model }} & \multicolumn{2}{|c|}{$\begin{array}{l}\text { Unstandardized } \\
\text { Coefficients }\end{array}$} & \multirow{2}{*}{$\begin{array}{l}\text { Standardized } \\
\text { Coefficients }\end{array}$} & \multirow[b]{2}{*}{$\mathrm{t}$} & \multirow[b]{2}{*}{ Sig. } \\
\hline & & B & Std. Error & & & \\
\hline \multirow[t]{2}{*}{1} & (Constant) & 10.877 & 5.381 & & 2.021 & .050 \\
\hline & $X$ & .766 & .133 & .668 & 5.743 & .000 \\
\hline
\end{tabular}

a. Dependent Variable: Y

Berdasarkan tabel 11 diatas diperoleh $t_{\text {hitung }}$ sebesar 5,743. Dengan menggunakan tingkat signifikansi $(\alpha)$ sebesar 0,05 dan derajat kebebasan $n-2$, maka diperoleh nilai $t_{\text {tabel }}$ sebesar 1,68. Dengan demikian dapat ditarik kesimpulan bahwa Ho ditolak karena berdasarkan perhitungan uji $\mathrm{t}$ diperoleh bahwa $\mathrm{t}_{\text {hitung }}>\mathrm{t}_{\text {tabel }}$ yaitu 5,743 $>1,68$. Hal tersebut merupakan kriteria penerimaan $\mathrm{Ha}$ yaitu audit manajemen sumber daya manusia (X) berpengaruh terhadap kinerja karyawan (Y).

\section{Koefisien Determinasi $\left(\mathbf{R}^{2}\right)$}

Tabel 12

Hasil Uji Koefisien Determinasi $\left(\mathbf{R}^{2}\right)$

\begin{tabular}{|l|l|l|l|l|}
\hline \multirow{2}{*}{ Model } & $\mathrm{R}$ & Model Summary & \\
\hline 1 & $.668^{\mathrm{a}}$ & .446 & Adjusted R Square & $\begin{array}{l}\text { Std. Error of } \\
\text { the Estimate }\end{array}$ \\
\hline
\end{tabular}

a. Predictors: (Constant), $\mathrm{X}$

b. Dependent Variable: Y

Berdasarkan tabel 12 diatas diperoleh nilai koefisien determinasi $\left(\mathrm{R}^{2}\right)$ sebesar $0,446=$ $44,6 \%$. Artinya, besarnya pengaruh variabel audit manajemen sumber daya manusia (X) terhadap kinerja (Y) adalah sebesar 44,6\%, sedangkan sisanya sebesar 55,4\% dipengaruhi oleh faktor-faktor lain diluar penelitian ini. 


\section{Kesimpulan dan Saran}

\subsection{Kesimpulan}

1. Berdasarkan hasil analisis data yang telah dilakukan, diperoleh hasil yang menyatakan bahwa Audit Manajemen Sumber Daya Manusia berpengaruh terhadap kinerja karyawan dengan nilai koefisien korelasi yang termasuk kedalam kategori kuat. Hal ini menyatakan keberadaan Audit Manajemen Sumber Daya Manusia dengan tingkat keeratan kuat. Adapun kontribusi Audit Manajemen Sumber Daya Manusia terhadap kinerja karyawan pada PT. Gramedia Asri Media Bandar Lampung juga cukup tinggi.

2. Berdasarkan hasil pengujian hipotesis dengan menggunakan uji $t$ dapat ditarik kesimpulan bahwa Ho ditolak karena berdasarkan perhitungan uji t diperoleh bahwa $t_{\text {hitung }}>t_{\text {tabel }}$. Hal tersebut merupakan kriteria penerimaan Ha yaitu audit manajemen sumber daya manusia berpengaruh terhadap kinerja karyawan.

\subsection{Saran}

1 Dalam hubungannya dengan audit manajemen sumber daya manusia, Perusahaan dalam hal ini PT. Gramedia Asri Media Bandar Lampung sebaiknya harus lebih mempersiapkan perencanaan tenaga kerja dimasa yang akan datang, baik dalam arti jumlah dan kualifikasinya untuk mengisi berbagai bidang atau jabatan yang dibutuhkan sesuai dengan ketersediaan sumber daya manusia.

2 Untuk lebih meningkatkan kinerja sumber daya manusia, perusahaan dalam hal ini PT. Gramedia Asri Media Bandar Lampung harus lebih meningkatkan perhatiannya dalam hal kejelasan tentang jenjang karier bagi setiap karyawan, keamanan karyawan dalam bekerja, suasana lingkungan kerja, dan berkesempatan untuk memunculkan ide-ide atau kreativitas baru. 


\section{Daftar Pustaka}

Agoes, Sukrisno. 2004. Auditing (Pemeriksaan Akuntan) oleh Kantor Akuntan Publik. Jakarta: Lembaga Penerbitan FEUI.

Arens, Alvin A., and James K Loebbecke. 2010. Auditing an Integrated Approach. New Jersey. Prentice Hall Inc.

Bacal, Robert. 2002. Performance Management (Alih Bahasa: Dharma \& Irawan), Jakarta: PT. Gramedia Pustaka Utama.

Bayangkara, IBK. 2011. Management Audit: Prosedur dan Implementasi. Jakarta: Salemba Empat.

Byars and Rue. 2004.Human Resource Management: A Practical Approach. Harcourt Brace. New York.

Ghozali, Imam, 2009. Aplikasi Analisis Multivariate Dengan Program SPSS, Edisi Keempat, Penerbit Universitas Diponegoro.

Hamilton, Alexander. 2008. Management Audit: Maximizing Your Company efficiency and effectiveness.

Handoko, T.Hani. 2004. Manajemen Personalia dan Sumber Daya Manusia. BPFE Yogyakarta.

Husein, Umar. 2002. Evaluasi Kinerja Perusahaan. Jakarta: PT Gramedia Pustaka Utama.

Irawan, Prasetya. 2007. Penelitian Kualitatif dan Kuantitatif untuk Ilmu-ilmu Sosial. DIA FISIP UI. Jakarta.

Mulyadi. 2009. Auditing Edisi 6 Buku 1. Jakarta: Salemba Empat.

Schermerhorn, Jhon R., James G.Hunt, \& Richard N. Osborn. 1999. Managing Organizational Behavior. New York: John Wiley \& Sons Inc.

Siagian, Sondang, P. 2001. Audit Manajemen. Cetakan Ketiga. Jakarta: PT Bumi Aksara.

Sugiyono. 2011. Metode Penelitian Kuantitatif kualitatif dan R\&D. Bandung: CV Alfabeta. 